\author{
Monika Borowiec \\ Zakład Przedsiębiorczości i Gospodarki Przestrzennej \\ Instytut Geografii \\ Akademia Pedagogiczna im. KEN w Krakowie
}

\title{
Etyczne aspekty globalizacji w procesie kształtowania przedsiębiorczości
}

Postępująca globalizacja w decydującym stopniu wpływa na polaryzację przestrzeni światowej i w coraz większym zakresie różnicuje jakość życia społeczno-gospodarczego. Dlatego też wydaje się niezbędne podjęcie pogłębionych studiów nad ograniczaniem tych niekorzystnych współczesnych trendów na podstawie zasad etyki, którymi powinno kierować się życie społeczno-gospodarcze. Szczególne znaczenie w tym względzie ma kształtowanie przedsiębiorczości, w której uwrażliwia się młodych ludzi na sprawy człowieka jako podmiotu w zarządzaniu i gospodarowaniu w określonych strukturach społecznych. Można przyjać, że problematyka etyki w życiu społecznogospodarczym w globalizującym się świecie jest bardzo istotnym i aktualnym zagadnieniem, które należy podjać w procesie edukacyjnym ${ }^{1}$. Zakładamy, że kształtowanie postaw etycznych powinno się opierać na treściach kształcenia. Sprzyjają temu treści kształcenia przedmiotu ,podstawy przedsiębiorczości”, przede wszystkim kwestie globalizacji, gospodarki rynkowej, funkcjonowania przedsiębiorstwa oraz komunikacji interpersonalnej, z uwzględnieniem etyki zawodowej. Celem kształcenia uczniów w tej dziedzinie jest zdobycie przez nich podstawowych umiejętności w zakresie rozumienia procesów społeczno-gospodarczych oraz funkcjonowania we współczesnym świecie różnej skali podmiotów gospodarczych, analizy i rozumienia podstawowych mechanizmów ekonomicznych we współczesnych systemach zarządzania gospodarką i firmą w zróżnicowanej przestrzeni geograficznej oraz zdobycie umiejętności konkurencyjnego zachowania się na rynku pracy (Borowiec 2005). Oprócz treści merytorycznych, istotnym celem kształcenia powinno być kształtowanie postaw przedsiębiorczych opartych na zasadach etyki. W wyniku procesu dydaktycznego uczeń powinien rozumieć, dlaczego działalność gospodarczą należy oceniać nie tylko w kategoriach ekonomicznych, ale i etycznych, oraz doceniać znaczenie przestrzegania zasad etycznych przez przedsiębiorstwa i pracowników, wiedzieć na czym polegają etyka zawodowa, etyka biznesu oraz społeczna odpowiedzialność firmy.

Te kwestie akcentuje się w programie studiów geograficznych na specjalności „przedsiębiorczość i gospodarka przestrzenna" w Akademii Pedagogicznej im. Komisji Edukacji Narodowej w Krakowie w treściach przedmiotowych, m.in.: ,zarządzania firmą”, ,polityki społecznej”, polityki gospodarczej”, ,integracji europejskiej”.

\footnotetext{
${ }^{1}$ Wyrazem zrozumienia znaczenia tych kwestii we współczesnym świecie jest m.in. powołanie w Warszawie w 1999 r. - z inicjatywy Wyższej Szkoły Przedsiębiorczości i Zarządzania im. Leona Koźmińskiego oraz Instytutu Filozofii i Socjologii Polskiej Akademii Nauk - Centrum Etyki Biznesu (CEBI). CEBI ma stanowić główny ośrodek badań i studiów na rzecz rozwoju tej dyscypliny w Polsce oraz miejsce spotkania liderów biznesu i świata akademickiego, którym zależy na promowaniu etyki życia społeczno-gospodarczego (www.cebi.pl).
} 
Konsekwencje procesów globalizacji są przedmiotem dyskusji w świetle zasad etycznych i społecznej nauki Kościoła, podczas których zwraca się uwagę na szanse i zagrożenia, a na tym tle podejmuje się rozważania na temat postaw etycznych przedsiębiorcy.

W dalszych rozważaniach wstępnie za J. Wilkinem (2003) przyjęto, że globalizacja cechuje się: 1. zagęszczaniem i intensyfikacją więzi między różnymi podmiotami (jednostki ludzkie, przedsiębiorstwa, władze lokalne, regionalne, rządy państw, korporacje międzynarodowe, organizacje pozarządowe, instytucje międzynarodowe) w skali światowej);

2. szybkością wzajemnego oddziaływania w ramach systemu światowego wynikająca przede wszystkim z niezwykłego postępu w dziedzinie informatyzacji i telekomunikacji;

3. zwiększającą się otwartością struktur instytucjonalnych;

4. intensyfikacją wzajemnego przenikania się każdej sfery życia, obejmującą coraz silniej wszystkie dziedziny życia: warunki gospodarowania, strukturę konsumpcji, sposoby spędzania czasu wolnego, programy nauczania, zawartość podręczników, życie kulturalne, praktyki religijne. Globalizacja traktowana jest więc jako intensyfikacja wzajemnych powiązań przestrzennych w skali światowej.

W rozwiązywaniu aktualnych globalnych problemów konieczne jest współdziałanie etyki, ekonomii i polityki (Adamus-Matuszyńska, 1999). Wydaje się zatem, że postępujące procesy globalizacyjne powinny sprzyjać wspólnemu angażowaniu się w problemy całego świata, takie jak nasilanie się dysproporcji społecznych i ekonomicznych, bezrobocia i ubóstwa, zanieczyszczenie środowiska, konflikty etniczne i religijne, rozprzestrzenianie się chorób zakaźnych, przestępczość międzynarodowa.

W literaturze przedmiotu rozwinęła się bardzo szeroka dyskusja dotycząca szans i zagrożeń wynikających z postępującego procesu globalizacji (tab.1).

Tab. 1. Szanse i zagrożenia wynikające z postępującego procesu globalizacji

\begin{tabular}{|l|l|}
\hline \multicolumn{1}{|c|}{ Szanse } & \multicolumn{1}{c|}{ Zagrożenia } \\
\hline \multicolumn{1}{|c|}{1} & \multicolumn{1}{c|}{2} \\
\hline Globalizacja wzbogaca kulturę. & $\begin{array}{l}\text { Globalizacja powoduje ,amerykanizację” całego } \\
\text { świata (Palmer, 2003), ujednolicenie kultury (ho- } \\
\text { mogenizację, uniformizację). }\end{array}$ \\
\hline $\begin{array}{l}\text { Globalizacja prowadzi do pokoju przez ograni- } \\
\text { czanie zachęt do wywoływania konfliktów (Pal- } \\
\text { mer, 2003). }\end{array}$ & $\begin{array}{l}\text { Globalizacja poprzez procesy polaryzacyjne } \\
\text { może pogłębiać konflikty na świecie. }\end{array}$ \\
\hline $\begin{array}{l}\text { Globalizacja sprzyja podejmowaniu wspólnych } \\
\text { działań w walce z zagrożeniami nasilającego się } \\
\text { fundamentalizmu. }\end{array}$ & $\begin{array}{l}\text { Fundamentalizm to „dziecko globalizacji” (Gid- } \\
\text { dens, 2000). Fundamentalizm jako reakcja obron- } \\
\text { na na hegemonię kulturowo-cywilizacyjną strefy } \\
\text { euratlantyckiej, a zwłaszcza Stanów Zjednoczo- } \\
\text { nych (Wnuk-Lipiński, 2004). }\end{array}$ \\
\hline $\begin{array}{l}\text { Globalizacja tworzy dobrobyt i przynosi korzyści } \\
\text { wszystkim (Palmer, 2003). }\end{array}$ & $\begin{array}{l}\text { Globalizacja powoduje narastanie dystansów } \\
\text { i dysproporcji rozwojowych oraz nasilanie się } \\
\text { nierówności (Wilkin, 2003). }\end{array}$ \\
\hline $\begin{array}{l}\text { Globalizacja stwarza duże szanse i możliwości } \\
\text { przyspieszania wzrostu gospodarczego i powięk- } \\
\text { szania bogactwa we wszystkich państwach. }\end{array}$ & $\begin{array}{l}\text { Szanse wynikające z nasilenia globalizacji nie są } \\
\text { takie same i jednakowo dostępne wszystkim. Naj- } \\
\text { większe możliwości globalizacja stwarza wypo- } \\
\text { sażonym w najbardziej mobilne czynniki, przede } \\
\text { wszystkim w kapitał finansowy. }\end{array}$ \\
\hline
\end{tabular}


Tab. 1. Szanse i zagrożenia wynikające z postępującego procesu globalizacji (cd.)

\begin{tabular}{|c|c|}
\hline 1 & 2 \\
\hline $\begin{array}{l}\text { Wolny handel jest najszybszym sposobem elimi- } \\
\text { nacji zjawiska zatrudniania dzieci (Palmer, 2003). }\end{array}$ & Globalizacja powoduje wzrost zatrudnienia dzieci. \\
\hline $\begin{array}{l}\text { Handel, otwartość i globalizacja wspierają rządy } \\
\text { demokratyczne i państwo prawa (Palmer, 2003). } \\
\text { Wolny handel należy do podstawowych praw czło- } \\
\text { wieka. }\end{array}$ & $\begin{array}{l}\text { Globalizacja wiąże się z brakiem gwarancji praw } \\
\text { obywatelskich, brakiem możliwości kontrolowania } \\
\text { gospodarki przez instytucje społeczeństwa obywa- } \\
\text { telskiego oraz demokratycznie wyłaniane władze } \\
\text { państwowe w systemie globalnym (Wilkin, 2003). }\end{array}$ \\
\hline Globalizacja powoduje poszerzanie wolności. & $\begin{array}{l}\text { Globalizacja powoduje dominację sfery „mieć” } \\
\text { nad sfera „być”. }\end{array}$ \\
\hline Wzrost gospodarczy oznacza wzrost dobrobytu. & $\begin{array}{l}\text { Wzrost gospodarczy nie zawsze wiąże się z po- } \\
\text { prawą standardu i jakości życia. }\end{array}$ \\
\hline $\begin{array}{l}\text { Globalizacja zwiększa wydajność pracy, konku- } \\
\text { rencyjność jednostek i przedsiębiorstw. }\end{array}$ & $\begin{array}{l}\text { Globalizacja wspiera kulturę rywalizacji. Wzrost, } \\
\text { ekspansja, maksymalizacja - stały się dominujący- } \\
\text { mi wartościami w świecie biznesu (Wilkin, 2003). }\end{array}$ \\
\hline Globalizacja zmniejsza liczbę miejsc pracy. & $\begin{array}{l}\text { Globalizacja nie wpływa na liczbę miejsc pracy, } \\
\text { ale na rodzaj wykonywanej pracy (Palmer, 2003). }\end{array}$ \\
\hline Różnorodność konsumpcji, indywidualizm. & $\begin{array}{l}\text { Hedonizm w konsumpcji, brak umiaru, a także } \\
\text { brak środków finansowych na zaspokojenie ro- } \\
\text { snących potrzeb konsumpcyjnych, a w konse- } \\
\text { kwencji wzrost przestępczości i patologii. }\end{array}$ \\
\hline $\begin{array}{l}\text { Globalizacja zwiększa szybkość przepływu kapi- } \\
\text { tału, usług i ludzi oraz ich mobilność, ułatwia kon- } \\
\text { takty międzyludzkie. }\end{array}$ & $\begin{array}{l}\text { Tymczasowość i nietrwałość przenosi się także na } \\
\text { układy społeczne, powodując dezintegrację prze- } \\
\text { strzeni społecznej, zmniejszenie poczucia bezpie- } \\
\text { czeństwa, a egzystencjalne zagubienie utrudnia od- } \\
\text { powiedzialne pełnienie różnych ról społecznych } \\
\text { (Dylus, 2004). }\end{array}$ \\
\hline Globalizacja umożliwia wolny przepływ kapitału. & $\begin{array}{l}\text { Globalizacja to groźba globalnej katastrofy finan- } \\
\text { sowej (Wilkin, 2003). }\end{array}$ \\
\hline $\begin{array}{l}\text { Układ porządku światowego zależy od potencjału } \\
\text { gospodarczego, technologicznego i naukowego, } \\
\text { a nie wyłącznie od potencjału militarnego i lud- } \\
\text { nościowego. }\end{array}$ & $\begin{array}{l}\text { Układ porządku światowego kształtują najbogat- } \\
\text { sze państwa („,kraje rdzenia globalizacji”). }\end{array}$ \\
\hline $\begin{array}{l}\text { Globalizacja zwiększa możliwości zaspokajania } \\
\text { potrzeb, przyspiesza rozwój nowych technologii, } \\
\text { przyczynia się do zwiększenia jakości i długości } \\
\text { życia. }\end{array}$ & $\begin{array}{l}\text { Globalizacja zaspokaja potrzeby luksusu bądź } \\
\text { kreuje potrzeby u wąskiej grupy najbogatszych } \\
\text { ludzi, pomijając podstawowe potrzeby szerokich } \\
\text { kręgów społecznych. }\end{array}$ \\
\hline $\begin{array}{l}\text { Globalizacja powoduje skracanie życia produktów, } \\
\text { przyspieszenie obrotów, zwiększenie zysków, } \\
\text { tworzenie nowych rynków zbytu i ciagłe powięk- } \\
\text { szanie PKB (Wilkin, 2003). }\end{array}$ & $\begin{array}{l}\text { Globalizacja powoduje wielkie marnotrawstwo } \\
\text { zasobów, w tym nieodnawialnych. }\end{array}$ \\
\hline $\begin{array}{l}\text { Wspólna polityka w zakresie ochrony środowiska } \\
\text { przyrodniczego. }\end{array}$ & $\begin{array}{l}\text { Globalizacja jest odpowiedzialna za niszczenie } \\
\text { środowiska przyrodniczego. }\end{array}$ \\
\hline $\begin{array}{l}\text { Globalizacja nie jest zagrożeniem dla państw na- } \\
\text { rodowych (Morawski, 2004). }\end{array}$ & $\begin{array}{l}\text { Globalizacja jest zagrożeniem dla państw narodo- } \\
\text { wych. }\end{array}$ \\
\hline
\end{tabular}


Za układ odniesienia oceny postępującego procesu globalizacji oraz roli człowieka w rozwoju cywilizacyjnym można przyjąć naukę społeczną Kościoła zawartą w kolejnych społecznych encyklikach papieskich, z których najistotniejsze przedstawia J. Auleytner (2002) w pracy Polityka spoleczna, czyli ujarzmianie chaosu socjalnego.

Znaczącą rolę w tym zakresie odegrała encyklika Rerum novarum (1891) Leona XIII, która odnosi się do idei własności prywatnej, akcentuje idee sprawiedliwości społecznej i określa wpływ państwa na dobro ogółu. Postuluje ona współpracę jako istotę życia gospodarczego. Państwo powinno troszczyć się o dobro ogółu, co oznacza opiekę nad warstwami najsłabszymi ekonomicznie, ale nie może zmniejszać aktywności jednostki. Przyjęto zatem zasadę ograniczonej interwencji państwa ze względu na dobro ogółu, obejmującej m.in.: ochronę własności prywatnej, pracy, ochronę kobiet i dzieci przed wyzyskiem pracodawców, zasadę sprawiedliwej płacy.

Problematyka ta została podjęta także w Quadragesimo anno $(1931)^{2}$ Piusa XI, w której zwrócono uwagę na pomocniczy charakter interwencji państwa i uznanie pierwszeństwa inicjatywy oddolnej. Państwo powinno zapewniać funkcje kontrolne, kierownicze, motywacyjne oraz związane z karaniem nadużyć.

W encyklice Mater et Magistra (1961) Jana XXIII podkreślana jest konieczność realizacji przez państwo wspólnego dobra oraz konieczność przestrzegania praw i obowiązków określających porządek między ludźmi, opartych na odpowiedzialności, prawdzie, wolności i sprawiedliwości, m.in.:

1. prawa do życia i godnej stopy życiowej,

2. prawa do prawdy,

3. prawa do wolnego wyboru stanu cywilnego i swobody życia rodzinnego,

4. prawa do godziwych warunków pracy,

5. prawa do podejmowania działalności gospodarczej,

6. prawa do sprawiedliwego wynagrodzenia,

7. prawa do własności prywatnej,

8. prawa do zrzeszania się,

9. prawa do migracji,

10. prawa do udziału w życiu publicznym.

Interwencja państwa powinna ograniczać się do popierania, pobudzania, koordynowania, pomocy i uzupełniania podejmowanych inicjatyw indywidualnych.

W Laborem exercens z 1981 r. Jan Paweł II podkreśla, że praca ludzka stanowi klucz do rozwiązania kwestii społecznej. Państwo powinno planować i organizować zatrudnienie, a bezrobocie wymaga przeciwdziałania. Obowiązkiem pracodawcy zaś jest stwarzanie godziwych warunków pracy oraz sprawiedliwe wynagradzanie.

W kolejnej encyklice Solilicitudo rei socialis z 1987 r. Jan Paweł II krytykuje cywilizację konsumpcji. Podkreśla w niej, że rzeczywisty rozwój nie powinien być redukowany do wymiaru ekonomicznego; oznacza on poszanowanie i realizację praw człowieka, a istotną w nim rolę odgrywa zasada solidarności - wola zaangażowania się na rzecz dobra wspólnego. Jan Paweł II zauważa, że ograniczanie prawa do inicjatywy gospodarczej niszczy przedsiębiorczość, która jest ważna nie tylko w wymiarze jednostkowym, ale także ogólnospołecznym.

\footnotetext{
${ }^{2}$ Por. J. Karp, Rola zasady subsydiarności we wspótczesnym państwie [w:] Prawo i ustrój Rzeczypospolitej Polskiej w perspektywie integracji z Uniq Europejskq, M. Grzybowski, M. Berdel-Dudzińska (red.), Wyższa Szkoła Informatyki i Zarządzania, Rzeszów 2002.
} 
Podobnie w Centesimus annus z 1991 r. $^{3}$ Jan Paweł II krytykuje model społeczeństwa konsumpcyjnego pomijającego wartości duchowe i opowiada się za nowym modelem społeczeństwa, w którym istniałaby wolność pracy, uczestnictwo i przedsiębiorczość. Istotnym składnikiem wolnego rynku, bez którego nie mógłby on spełniać swojej roli, jest wolna przedsiębiorczość. Podkreśla również, że ideały demokracji wymagają oparcia na prawach człowieka chronionych przez państwo, które ma gwarantować bezpieczeństwo w działalności gospodarczej oraz stosować zasadę pomocniczości poprzez tworzenie warunków dla inicjatyw oddolnych. Jednostka powinna być odpowiedzialna za własny rozwój. Jan Paweł II akceptowaną przez Kościół postać kapitalizmu nazywa „ekonomią przedsiębiorczości”, która w encyklice tej określana jest jako system ekonomiczny uznający podstawową i pozytywną rolę przedsiębiorstwa, własności prywatnej i wynikającej z niej odpowiedzialności środków produkcji (Zboroń 1998).

Współcześnie w nauce społecznej Kościoła przyjmuje się podstawowe zasady odnoszące się do godności człowieka i przeciwstawiające się wszelkim formą dyskryminacji. Oto zasady nauki społecznej Kościoła:

1. zasada dobra wspólnego - oznacza, że władze publiczne powinny działać na korzyść wszystkich obywateli, a polityka społeczna - harmonizować często sprzeczne interesy ${ }^{4}$;

2. zasada solidarności - oznacza mocną i trwałą wolę angażowania się na rzecz wspólnego dobra i odpowiedzialność wszystkich za wszystkich ${ }^{5}$;

3. zasada pomocniczości-oznacza pierwszeństwo inicjatywy oddolnej, która chroni autonomię i podmiotowość wspólnot lokalnych. Zamiast postaw roszczeniowych wskazuje ona, że rozwiązywanie problemów zależy przede wszystkim od indywidualnej zaradności, aktywności, inicjatywy i zdolności jednostek ${ }^{6}$;

4. zasada uczestnictwa - uczestnictwo pojmowane jest jako szansa realizacji praw człowieka, wyraża bowiem jego godność i wolność oraz umożliwia rozwój’;

5. zasada proporcjonalnego rozwoju - zakłada równomierny i harmonijny rozwój umożliwiający ludziom realizację ich szans rozwoju.

Zasady te pozostają w związku z aksjologią, z wartościami prawdy, wolności, sprawiedliwości, solidarności, pokoju i miłości, wskazując na pierwszeństwo etyki przed techniką (Auleytner 2002). Zapewnienie sprawiedliwości społecznej przez społeczeństwo dokonuje się wtedy, gdy respektuje ono godność i prawa ludzkie (Kompendium Katechizmu Kościoła Katolickiego 2005). Sprawiedliwość społeczna została uszczegółowiona w postaci szeregu zasad konstytucyjnych, będących fundamentem państwa demokratycznego (Karp 2004). Zasady te wyrażają wartości, które powinny być chronione w każdej sferze życia: osobistej (np. prawo do życia,

\footnotetext{
${ }^{3}$ Por. o. dr M. Ziemba, rozprawa doktorska Kościót wobec demokratycznego kapitalizmu w świetle encykliki ,Centesimus Annus”.

${ }^{4}$ Według Kompendium Katechizmu Kościoła Katolickiego (2005, s. 133): „Dobro wspólne obejmuje: poszanowanie i popieranie podstawowych praw osoby ludzkiej; dobrobytu, czyli wzrostu dóbr duchowych i ziemskich poszczególnych ludzi i społeczności; pokoju i bezpieczeństwa wszystkich".

${ }^{5}$ Por. B. Sutor, Etyka polityczna, „Kontrast” Wydawnictwo Fundacji ATK, Warszawa 1994.

${ }^{6}$ Według Kompendium Katechizmu Kościoła Katolickiego (2005): „Zasada pomocniczości polega na nieingerowaniu społeczności wyższego rzędu w wewnętrzne sprawy społeczności niższego rzędu, pozbawiając ją kompetencji, lecz na wspieraniu w razie konieczności".

${ }^{7}$ Według Kompendium Katechizmu Kościoła Katolickiego (2005): „Solidarność przejawia się przede wszystkim w sprawiedliwym podziale dóbr, w wynagrodzeniu za pracę oraz zakłada wysiłek na rzecz bardziej sprawiedliwego porządku społecznego".
} 
wolność słowa, wolność wyznania), politycznej (np. prawo do zrzeszania się, udziału w życiu publicznym), ekonomicznej (np. wolność działalności gospodarczej, ochrona własności) oraz socjalnej (np. nadzór państwa nad warunkami wykonywania pracy).

Kwestia etycznego wymiaru globalizacji została szeroko omówiona na VII Sesji Plenarnej Papieskiej Akademii Nauk Społecznych w Watykanie, 27.04.2001 r. Przyjęto, że globalizacja nie jest a priori ani dobra, ani zła; będzie taka, jaką uczynią ją ludzie ${ }^{8}$. Podkreślano, że żaden system nie jest celem samym w sobie i że globalizacja, jak każdy inny system, musi służyć człowiekowi, solidarności i dobru wspólnemu. Powszechne dobro wymaga, aby wewnętrzna logika rynku podlegała pewnym mechanizmom kontrolnym i aby respektowała podstawowe wartości ludzkie i dobro wspólne. Afirmacja pierwszeństwa etyki odpowiada zasadniczej potrzebie człowieka i ludzkiej wspólnoty. Wartości etyczne nie mogą podlegać dyktatowi nowych wynalazków, techniki ani wydajności, są bowiem zakorzenione w samej naturze człowieka, a etyka nie może być usprawiedliwieniem ani uzasadnieniem systemu, ale powinna być zabezpieczeniem wszystkiego, co ludzkie w każdym systemie.

Podstawowe zasady etyczne w procesie globalizacji polegają zatem:

- ,po pierwsze na niezbywalnej wartości człowieka, która jest źródłem wszelkich praw ludzkich i wszelkiego ładu społecznego. Człowiek musi być zawsze celem, a nie środkiem, podmiotem, a nie przedmiotem ani towarem rynkowym;

- po drugie, na wartości ludzkich kultur, których żadna władza nie ma prawa lekceważyć ani tym bardziej niszczyć - globalizacja nie może być nową postacią kolonializmu, musi respektować wielość kultur, które w ramach powszechnej harmonii narodów są jakby różnymi kluczami interpretacyjnymi ludzkiego życia” (ks. Mariański 2003, s. 61).

Ludzkość wkraczająca w erę globalizacji nie może się obejść bez wspólnego kodeksu etycznego, przy całej różnorodności form kultury istnieją bowiem uniwersalne wartości ludzkie, które należy stawiać na pierwszym planie, jako wiodącą siłę wszelkiego rozwoju i postępu. Już podczas V Zgromadzenia Ogólnego Papieskiej Akademii Nauk Społecznych 6.03.1999 r. Jan Paweł II podkreślał, że ,globalizacja ekonomii i pracy wymaga także globalizacji odpowiedzialności9 .

Jak przyjmuje A. Adamus-Matuszyńska (1999), etyka polega na określaniu dobra i zła, formułowaniu reguł ułatwiających dokonywanie wyborów, wskazywaniu elementów życia społecznego wymagających szczególnej troski społecznej, ochraniających jednostkę i jej godność przed krzywda, niedostatkiem, brakiem równości czy sprawiedliwości. Powinna zatem regulować działania społeczne oraz wskazywać źródła i sposoby unikania niebezpieczeństw.

Etykę biznesu można definiować jako reguły, standardy postępowania i kodeksy lub zasady, które dostarczają wskazówek, jak uczciwie postępować w działalności gospodarczej (Hansen 1993). Etyka biznesu kładzie nacisk na znaczenie praw człowieka akceptowanych niezależnie od przynależności narodowej, kulturowej czy religijnej, określonych w Deklaracji Praw Człowieka oraz zapisanych w Karcie Praw Podstawowych Unii Europejskiej, takich jak prawo do wolności słowa i zrzeszania się, migracji, własności, sprawiedliwych sądów, niedyskryminacji, utrzymania się przy życiu, uczestnictwa w życiu politycznym, bezpieczeństwa. Obowiązki międzynarodowego biznesu obejmują (De George 1993):

1. szanowanie praw człowieka,

2. szanowanie lokalnej kultury,

3. niewyrządzanie świadomej szkody,

\footnotetext{
${ }^{8} \mathrm{http} / / /$ www.opoka.org.pl/biblioteka/W/WP/jan_pawel_ii/przemowienia/globalizacja_27042001.html

9 „L'Osservatore Romano”, 5-6/1999, s. 55.
} 
4. wytwarzanie większej ilości dóbr niż szkód dla kraju goszczącego oraz uczestniczenie w jego rozwoju,

5. współpracę z lokalnym rządem,

6. uczciwe opłacanie podatków,

7. uznawanie kontroli firm,

8. zabezpieczanie ryzykownych zasobów,

9. odpowiedzialne i uczciwe stosowanie ryzykownych technologii transferowanych do krajów słabiej rozwiniętych.

Przedsiębiorca zatem, dokonując wyborów ekonomicznych, powinien analizować pod względem moralnym zarówno swoje cele, jak i środki (Klimczak, 1999). Powinien charakteryzować się uczciwością, sprawiedliwością, mądrością, empatią, przeciwstawianiem pokusom sukcesu i łatwego zysku, szacunkiem dla człowieka, odpowiedzialnością, opanowaniem, przezornością. Podobnie K. Davis i R. Blomstrom (1975) podkreślają obowiązek podejmowania decyzji i działań, które nie tylko przyczyniają się do powiększania własnych zysków, ale również do pomnażania dobrobytu społecznego oraz zapobiegania zjawiskom negatywnym. Również J. Dudek (2003), nakreślając wzór osobowy przedsiębiorcy, wymienia następujące jego cechy: odpowiedzialność, przestrzeganie wskazań etyki, kompetencje zawodowe, szerokie aspiracje intelektualne pozwalające na nowatorskie działania i myślenie perspektywiczne, wysoki poziom kultury osobistej. Normy moralne, jak sprawiedliwość, prawdomówność i uczciwość, powinny więc regulować życie gospodarcze (Nawara 1999). W kształtowaniu postaw etycznych młodych ludzi konieczne jest zatem podkreślanie skutków nieetycznych zachowań poszczególnych uczestników życia gospodarczego, dla pracodawcy, przedsiębiorstwa, pracowników, klientów, społeczności lokalnych oraz funkcjonowania gospodarki, ponieważ od procesu edukacyjnego w istotnym stopniu zależy wykorzystanie szans związanych z nasilaniem się procesów globalizacji.

\section{Literatura}

1. Adamus-Matuszyńska A., Etyka - Ekonomia - Polityka - wspótzależność czy rozbieżność? [w:] Annales. Etyka w życiu gospodarczym, t. 2, Salezjańska Wyższa Szkoła Ekonomii i Zarządzania, Łódź 1999.

2. Auleytner J., Polityka społeczna, czyli ujarzmianie chaosu socjalnego, Wydawnictwo Wyższej Szkoły Pedagogicznej TWP w Warszawie, Warszawa 2002.

3. Borowiec M., Rola praktyk z przedsiębiorczości w kształceniu studentów geografii na specjalności „przedsiębiorczość i gospodarka przestrzenna [w:] Przedsiębiorczość a współczesne wyzwania cywilizacyjne, Z. Zioło, T. Rachwał (red.), Przedsiębiorczość - Edukacja nr 1, Wydawnictwo „MiWa” Kraków 2005.

4. Davis K., Blomstrom R., Busines and Society. Environoment and Responsibility, 3 ed., McGraw-Hill, New York 1975.

5. De George R., Competing in Integrity in International Business, Oxford Un Press, New York 1993.

6. Dudek J., Czy można zaprojektować wzór osobowy przedsiębiorcy? Kilka uwag historycznych i metodologicznych [w:] Annales. Etyka w życiu gospodarczym, t. 6, Salezjańska Wyższa Szkoła Ekonomii i Zarządzania, Łódź 2003.

7. Dylus A., Dylematy procesu globalizacji [w:] Annales. Etyka w życiu gospodarczym, t. 7, nr 1, Salezjańska Wyższa Szkoła Ekonomii i Zarządzania, Łódź 2004.

8. Giddens A., Runaway World. How Globalization Is Reshaping our Lives, Routledge, New York 2000, s. 67.

9. Hansen, G., Wprowadzenie do etyki biznesu [w:] „Etyka”, 26/1993. 
10. Held D., McGrew A., Globalization [w:] The Oxford Companion to Politics of the World, J. Krieger (red.), Oxford University Press, Oxford 2001.

11. Karp J., Sprawiedliwość społeczna, Księgarnia Akademicka, Kraków 2004.

12. Klimczak B., Moralna odpowiedzialność przedsiębiorcy [w:] Annales. Etyka w życiu gospodarczym, t. 2, Salezjańska Wyższa Szkoła Ekonomii i Zarządzania, Łódź 1999.

13. Kompendium Katechizmu Kościoła Katolickiego, Wydawnictwo Jedność, Kielce 2005.

14. Ks. Mariański J., Gospodarka rynkowa w ocenie społecznego nauczania Kościoła [w:] Annales. Etyka w życiu gospodarczym, t. 6, Salezjańska Wyższa Szkoła Ekonomii i Zarządzania, Łódź 2003.

15. Morawski W., Globalizacja: Wyzwania i problemy [w:] Wymiary życia społecznego. Polska na przełomie XX i XXI wieku, M. Morda (red.), Wydawnictwo Naukowe Scholar, Warszawa 2004.

16. Nawara P., Etyka a koncepcja wolnego rynku [w:] Annales. Etyka w życiu gospodarczym, t. 2, Salezjańska Wyższa Szkoła Ekonomii i Zarządzania, Łódź 1999.

17. Palmer T.G., Globalizacja jest bardzo dobra, tłum. Kamila Pajer, 2003; www.kapitalizm.republika.pl/ global.html

18. Wilkin J., Globalizacja - moje nadzieje i obawy; www.ceo.org.pl; Centrum Edukacji Obywatelskiej, głos autora w dyskusji poświęconej globalizmowi zorganizowanej przez redakcję Res Publiki Nowej 15.10.2003 r., toczącej się wokół zagadnień poruszonych w $\mathrm{nr}$ 7: http://www.ceo.org.pl/dokument.php?dzial $=1726 \& \mathrm{id}=25097$

19. Wnuk-Lipiński E., Świat międzyepoki, Wydawnictwo Znak, Instytut Studiów Politycznych PAN, Kraków 2004.

20. Zboroń H., Etyczny kapitalizm - katolicka wizja gospodarki [w:] Annales. Etyka w życiu gospodarczym, t. 1, Salezjańska Wyższa Szkoła Ekonomii i Zarządzania, Łódź 1998.

\section{Ethical Aspects of the Globalization in the Process of Shaping the Entrepreneurships}

The progressive process of globalization influences on polarization of the world in decisive degree and differentiates the quality of life in more and more greater range. It is important to make wide studies connected with limiting these unprofitable present trends, basing on rules of ethics, which should direct oneself life. Special meaning has education of entrepreneurship in this regard. According to author consequences of globalization should be talked over in light of ethical rules and social science, when we should turn attention to odds and attitudes of ethical businessmen. The chances connected to processes of globalization depend on forming ethical attitudes in education. 